\title{
The Flare of Xenophobia in America during Covid-19 Pandemic
}

\author{
Amanda Nur Fasya ${ }^{1 *}$, Ariya Jati $^{2}$ \\ ${ }^{1}$ Department of English, Faculty of Humanities, Diponegoro University, Semarang-Indonesia \\ ${ }^{2}$ Department of English, Faculty of Humanities, Diponegoro University, Semarang-Indonesia
}

\begin{abstract}
Covid-19 pandemic contribute in creating xenophobic attitudes among American people. Recently, there are many reports about AsianAmerican people or Chinese people in America facing racisms and xenophobic attitudes; moreover there are also reports that Asian-American and Chinese people attacked by Americans. The aim of this study is to know how bad xenophobia in the middle of pandemic in America by analysing the data and what kinds of xenophobic attitudes do AsianAmerican and Chinese people frequently received during Covid-19 pandemic by society in America. This study uses descriptive research method to know the phenomena of xenophobic attitudes and its circumstance that happen at the present. We collect the data from reports on the various articles or news regarding to Asian-American and Chinese people experiencing racisms and xenophobic attitudes. The results are show that Asian-American and Chinese people received verbal and nonverbal attacks by American people, that is Hate-speech and physical Attacks. Xenophobic attitudes through verbal and non-verbal attacks, such as hate-speech and physical attacks have been surfaced by Asian-American people.
\end{abstract}

\section{Introduction}

Covid-19 pandemic was initially found in Wuhan, China, on December 1st, 2019. This virus did not come from Wuhan, but the virus was first detected there. Various information about Covid-19 spread fast when the first time this virus was detected, which makes the intensity of the spread of misinformation vulnerable. There is too much information from reliable sources or non-reliable sources that people absorb. These lead people to be confused and get easily trust any information from many sources. Many misinformation that said Covid-19 virus comes from Wuhan, China, make many people easily take that as an intake, consequently, people will easily defend themselves with any various way when other people approach them as they may be scared with something that seemed will attack them or spread the virus to them.

This pandemic is contributing in create xenophobic attitudes among the American people. Xenophobia is the fear or scared of something strange or foreign. Usually, it is linked with fear or dislike with other people race, culture, country, religion, etc.

\footnotetext{
*Corresponding author: amandanufa@gmail.com
} 
Xenophobic people usually will defend themselves in various ways if they feel the condition around them threatens them. Many causes had led to the negative attitudes flourishing in America during this pandemic, especially xenophobic attitudes and Asianhate; the statement from Donald Trump as the president of U.S. 2020 also added the appearance to normalizing Asian-hate xenophobic attitudes towards Asian-American and Chinese people in America. Trump neglected the fact that WHO has already declared that the disease named coronavirus or COVID-19, he still continuously using terms "Chinese Virus" and "Kung Flu" because he assumed that this virus derived from China [1]. This bad condition led people in America to stay with their own beliefs to always combat AsianAmerican and Chinese people in America. They assumed that this attitude was very normal in this kind of situation. Lately, many reports have been about Asian-American or Chinese people in America facing Asian hate, xenophobic attitudes, and racisms. The data from Stop AAPI Hate organization [2] collected the reports which show that Chinese people received hatred the most $(42.2 \%)$, followed with Korean ethnic (14.8\%), Vietnamese ethnic $(8.5 \%)$, and last, Filipinos (7.9\%). These all raised research questions on what kinds of xenophobic attitudes do Asian-American and Chinese people frequently received during the Covid-19 pandemic by society in America.

The previous studies about Covid-19 have been conducted, as we have already analysed into three categories of researches: The effect of xenophobic attitudes toward minorities; Xenophobia and its correlation with other negative attitudes; and ways to cope with xenophobia. Asians and minority groups have to face innumerable adverse effects regarding increasing discrimination and xenophobia during COVID-19. The economic welfare of the Asian Americans has been affected by the bad stigmatization [3], not only affect the economic fields, but the Covid-19 pandemic also had the biggest impact on creating any negative attitudes of society in America, which led Asian-American; Chinesedescent people, suffering from the mental health issue, such as anxiety disease as they received many kinds of hatred and prejudice from American people. Asian-American youth's mental health and sense of self and identity will be surely affected by the xenophobia, racism, anti-Asian, and Covid-19; which they faced during this pandemic [4]. The improvement in health literacy is crucial because it can prevent the spread of false information, which have the potential in carrying the ideologies of xenophobia about coronavirus. Thus, the improvement will help individuals provide their capability regarding spot and determine sources of media to help prevent the spread of information related to xenophobic beliefs [5].

However, further research needs to be conducted as the previous studies mostly only dealt with the effect of xenophobia, the correlation with other negative attitudes, and how to cope with xenophobia. Further research is important to focus on the type or kinds of xenophobic attitudes that are frequently faced by Asian-American or Chinese people in America.

The purpose of this study is to discover and to identify kinds of negative attitudes that might be surfaced by Asian-American people and Chinese people throughout this pandemic by analysing the data from various articles or news regarding Asian-American and Chinese people who are experiencing racisms and xenophobic attitudes.

This study is important in order to understand what kinds of xenophobic attitudes do Asian-American people frequently faced. By understanding xenophobic attitudes, we might be easily formulated on how to prevent these events from happening again continuously and harming the Asian-American and Chinese people. Law enforcement agencies could also take note that any various ways of harming Asian-American and Chinese people should be a concern to be well-handled. 


\section{Method}

This study uses a descriptive research method to know the phenomena of xenophobic attitudes and its circumstance that happen at present, and then identify kinds of xenophobic attitudes faced by Asian-American and Chinese people in America. The note-taking technique is also used to record the information and data from various sources regarding reports of Asian-American and Chinese people experiencing Asian hate, xenophobic attitudes, and racisms. The data collected from reports on various articles and news from Vox; The New York Times; and Time.

\section{Result}

From the data reports, many discrimination and xenophobic attitudes have been received by Asian-American and Chinese people. As we have been analysed, most American people see Asian-American and Chinese people as "other", or not part of their society as they see there are differences or diversity among them, the theory of "otherness" or "othering" contribute to lead prejudice, xenophobia, and other negative attitudes alive. The distinction in culture, race, social, and religion of Eastern countries, Japan, and China-related with the concept of "otherness". Othering itself is characterised by defining whether people (Asian-Americans) belong to their society or not. This is a way for most of the top of the American racial hierarchy to maintain their current situation [6]. The report's data regarding AsianAmerican and Chinese people who were experiencing Asian hate, xenophobic attitudes, and racisms, from various articles and news from Vox, The New York Times, and Time, can be identified into two kinds: xenophobic attitudes, verbal and non-verbal.:

\subsection{Hate-speech}

Many Asian-American and Chinese people found surfacing hate speech from American people, mostly in public places. They also get followed by strange people before receiving hate speech or verbal slurs. Americans assumed that Chinese or Asian-American people had the virus on their bodies and seemed ready to spread to America. There are many ways that American people use to show their hatred towards Asian-American and Chinese people in America:

\subsubsection{Death-threat}

Abraham Choi, a Korean-American, received a very harsh word and death-threat from strange people when he was in the bathroom, that strange people told and cursed at him that people who have Asia-descent like him should die, it is because that strange people has stigmatization that people from other country or race like him (Asian) have the virus in their body. This incident also happens to Jay Koo, a Korean-American people who live in America; he also got death-threat from a man that the man will kill him because Jay assumed to be the carrier of the virus [7] from this incident, it shows that people of AsianAmerican or Chinese people get easily receiving death-threat from Americans in America. Thus, the Asian-American and Chinese people are in an unsafe situation every time, which makes them anxious every time they go out because this incident can happen at any time in their daily lives. Therefore, Asian-American and Chinese people need to feel secure whenever and wherever they have to face people outside. 


\subsubsection{Racial and Verbal Slurs}

Reports show that many Asian-Americans and Chinese people got harsh-called from Americans; they also received racial and verbal slurs from them as they seemed like Asiandescent people. Americans use many ways to express or show their xenophobic attitudes: yelling, shouting, and calling harshly. Reports data from Time, Justin Tsui, a ChineseAmerican, got called harshly as a 'chinks', he also asked strange people about his ethnicity overtly and harshly told him to go back to China and not bring the virus there. Similarly, this incident also happens to Rej Joo, who is also called a 'chinks' and receives sarcasm from strange people that he will put on his mask if people in front of him (Joo) is Chinese people. Hannah Wang also received verbal slurs as if she were Chinese; customers would not talk to her [7]. In Los Angeles, A Korean-American man was also receiving racial slurs in February [8]. The racial and verbal slurs from the victim's experiences show that Americans people will easily call them (Asia-descent) harshly if they seemed like an Asiadescent no matter if they were also an American or not, Americans people themselves still assumed that they are 'other' not part of their society.

\subsection{Physical Attacks}

Not only receiving verbal attacks but Asian-American and Chinese people in America also experiencing non-verbal attacks; there are many reports show that most Asian-American people and Chinese people got non-verbally attacked, data from Stop AAPI Hate organization from 2020-2021 show that there are $12.6 \%$ of people has already experienced physical attacks in America. Asian-American and Chinese people face many kinds of physical attacks, such as getting kicked, punched, death-gaze, spat, spit or coughed. For example, in reports from San Francisco, a girl named Yuanyuan Zhu got yelled at and spat as she walked to her gym place [9]; another report also shows that a Korean-American got physically attacked by a stranger who was spitting coughing on him. These show that this issue should be a concern by America because if they keep on neglecting this issue, the Asian-American and Chinese people will feel threatened all the time, which will lead to any serious issue happening.

We can see that there are many kinds of xenophobic attitudes received by AsianAmerican people and Chinese people, which are categorized into two attacks: verbal attacks and non-verbal attacks. These several xenophobic attitudes experienced by Asian-American people and Chinese people should be a concern of the government in America and Law enforcement agencies; they should take a responsibility to act decisively against these actions that harm Asian-American people and Chinese people in America.

\section{Discussion}

The primary purpose of this study is to know what kinds of xenophobic attitudes AsianAmerican and Chinese people frequently received during the Covid-19 pandemic by society in America. However, the findings of this study support the theory that we chose that is Othering theory; the results show that there are many kinds of ways of xenophobic attitudes that Asian-American and Chinese people experienced during the Covid-19 pandemic, they received verbal and non-verbal attacks, such as hate speech and physical attacks. These actions happen because American people still see Asian-Americans; Chinese people; and Asian-descent people in America as 'other' and 'other' here, which means that they were not part of their society. This is happening because they might think that Asian-American; Chinese people; and Asia-descent people in America are a foreigner or strange people who do not fit their society, the concept of 'othering' or 'otherness' itself related with the 
differences among society in one area, and is also linked with racial, religion, country, cultural differences.

This study has a limitation that focuses only on the kinds of xenophobic attitudes that Asian-American and Chinese people experienced during the Covid-19 pandemic received verbal and non-verbal attacks. Different results may be possible if there are different fields and various aspects; however, the method in this study has limited in this result. Any further research can be conducted in law and regulation plants in order to make further identification about the aftermath of these xenophobic attitudes toward Asian-American and Chinese people as a concern to make binding regulations and strict sanctions that can be functioned as a way to gives a learned effect to the doer of these xenophobic attitudes.

\section{Conclusion}

Asian-American people received xenophobic attitudes through verbal and non-verbal attacks, such as hate speech and physical attacks, which lead them to feel insecure and anxious all the time. These actions happen because American people still assume AsianAmerican; Chinese people; and Asia-descent people in America as 'other', Americans think that Asian-American; Chinese people; and Asia-descent people in America are foreigners or strange people who do not fit their society even if they were American itself, the concept of 'othering' or 'otherness' itself related with the differences among society in one area, and is also linked with racial, religion, country, cultural differences. The government and Law enforcement agencies should be concerned and focusing on this issue so that this issue will not cause a further aftermath.

\section{References}

1. S. A. Batasin, Combating Xenophobia in the Covid-19 Pandemic: The Importance of Health Literacy, Inquiries Journal, 12(7), (2020)

2. Stop AAPI Hate, (2020), National Report, Retrieved from https://stopaapihate.org/national-report-through-march-2021/

3. L. Y. Dhanani, B. Franz, Why public health framing matters: An experimental study of the effects of COVID-19 framing on prejudice and xenophobia in the United States, Social science \& medicine, 269 (2021)

4. H. L. Cheng, Xenophobia and Racism Against Asian Americans During the COVID19 Pandemic: Mental Health Implications, Journal of Interdisciplinary Perspectives and Scholarship, (2020)

5. S. A. Batasin, Combating Xenophobia in the Covid-19 Pandemic: The Importance of Health Literacy, Inquiries Journal, 12(7), (2020)

6. E. W. Said, Orientalism, (Pantheon Books New York, 1978)

7. A. P. Kambhampaty, (2020), I Will Not Stand Silent, 10 Asian Americans Reflect on Racism During the Pandemic and the Need for Equality, Retrieved from: https://time.com/5858649/racism-coronavirus/

8. L. Zhou, (2021), The long history of anti-Asian hate in America, explained Anti-Asian racism is nothing new in America, Retrieved from https://www.vox.com/identities/2020/4/21/21221007/anti-asian-racism-coronavirusxenophobia

9. S. Tavernise, Jr. Oppel, A. Richard, (March, 2020), Spit On, Yelled At, Attacked: Chinese-Americans Fear for Their Safety, Retrieved from: https://www.nytimes.com/2020/03/23/us/chinese-coronavirus-racist-attacks.html 
10. A. R. Gover, S. B. Harper, L. Langton, Anti-Asian Hate Crime During the COVID-19 Pandemic: Exploring the Reproduction of Inequality, American Journal of Criminal Justice, 45(4), 647-667 (2020) 